\title{
A Perilipin Gene from Clonostachys rosea f. Catenulata HL-1-1 Is Related to Sclerotial Parasitism
}

\author{
Zhan-Bin Sun, Shi-Dong Li, Zeng-Ming Zhong and Man-Hong Sun * \\ Key Laboratory of Integrated Pest Management in Crops, Ministry of Agriculture, \\ Institute of Plant Protection, Chinese Academy of Agricultural Sciences, Beijing 100081, China; \\ E-Mails: twins5616@126.com (Z.-B.S.); lisd@ieda.org.cn (S.-D.L.); zhongzengming@163.com (Z.-M.Z.) \\ * Author to whom correspondence should be addressed; E-Mail: sunmanhong@caas.cn; \\ Tel.: +86-10-8210-9583; Fax: +86-10-8210-9573.
}

Academic Editor: Bing Yan

Received: 9 January 2015 / Accepted: 2 March 2015 / Published: 9 March 2015

\begin{abstract}
Clonostachys rosea $\mathrm{f}$. catenulata is a promising biocontrol agent against many fungal plant pathogens. To identify mycoparasitism-related genes from $C$. rosea f. catenulata, a suppression subtractive hybridization ( $\mathrm{SSH}$ ) cDNA library of $C$. rosea $\mathrm{f}$. catenulata HL-1-1 that parasitizes the sclerotia of $S$. sclerotiorum was constructed. 502 clones were sequenced randomly, and thereby 472 expressed sequence tags (ESTs) were identified. Forty-three unigenes were annotated and exhibited similarity to a wide diversity of genes. Quantitative real -time PCR showed that a perilipin-like protein encoding gene, Per3, was up-regulated by 6.6 -fold over the control at $96 \mathrm{~h}$ under the induction of sclerotia. The full-length sequence of Per 3 was obtained via 5' and 3' rapid identification of cDNA ends. Overexpression of Per3 in HL-1-1 significantly enhanced the parasitic ability on sclerotia. The results indicated that Per 3 might be involved in the mycoparasitism of $C$. rosea $\mathrm{f}$. catenulata HL-1-1. This is the first report of a perilipin as a potential biocontrol gene in mycoparasites. The study provides usefu 1 insights into the interaction between $C$. rosea f. catenulata and fungal plant pathogens.
\end{abstract}

Keywords: clonostachys rosea f. catenulate; Sclerotinia sclerotiorum; sclerotia; perilipin; mycoparasitism; ESTs 


\section{Introduction}

Clonostachys rosea f. catenulate (syn. Gliocladium catenulatum) is a mycoparasite capable of antagonizing a range of fungal plant pathogens, such as Sclerotinia sclerotiorum, Rhizoctonia solani, Fusarium spp., and Pythium spp. [1-4]. It has been widely used as a biological control agent [5-8]. Mycoparasitism is an important characteristic of biological control agents; the mechanism of mycoparasitism was initially studied in a few mycoparasite-Fungus interactions. Steindorff et al. identified various genes encoding transporters and hydrolytic enzymes that were differentially expressed in Trichoderma harzianum TR274 growing on S. sclerotiorum cell walls compared with the glucose control [9]. However, the specific functions of these genes were not studied. Thus, screening key biocontrol-related genes and studying their functions to understand biocontrol mechanisms will contribute to improving the efficiency of biocontrol agents.

A variety of genes have been confirmed as associated with biological control of plant pathogens. In comparison with the wild strain, a transformant of Metarhizium anisopliae carrying a neurotoxin gene AalT from Androctonus australis exhibited a higher fungal toxicity to Manduca sexta and Aedes aegypti, and stronger pathogenicity against Hypothenemus hampei [10,11]. Overexpression of the Trichoderma harzianum ergl gene (involved in the synthesis of ergosterol) was suggested to improve the biocontrol ability of the Trichoderma strains and their interaction with plants [12]. Kosawang et al. [13] disrupted a zearalenone lactonohydrolase encoding gene, zhd101, from C. rosea, which resulted in weak control of a zearalenone-production fungus Fusarium graminearum. Dubey et al. [14] identified an ATP-binding cassette transporter encoding gene $a b c G 5$, disruption of which failed to protect barley seedlings from $F$. graminearium foot rot disease. It was also suggested that knockdown of a virulence related serine protease gene $p a c C$ attenuated the virulence of $C$. rosea to nematodes [15].

Perilipin is a lipid droplet protein that regulates fat storage and lipid homeostasis in organisms by responding to signals that stimulate triacylglycerol-degradation [16,17]. It can bind to the surface of lipid droplets of adipocytes and restrict the access of lipases [18]. Previous studies on the function of perilipins mainly focused on its role in cellular lipid metabolism in mammals. Tansey et al. found that a perilipin null mouse had less fat and a higher metabolic rate, and was resistant to diet-induced obesity, compared with normal mice [19]. The role of perilipin has also been studied in Drosophila, where deletion of a perilipin encoding gene, $L s d 2$, decreased the level of neutral lipids [20]. Although perilipin has been identified from fungal species, limited research on its function has been conducted. A perilipin homolog, MPL1, from M. anisopliae was reported to regulate lipid metabolism, appressorial turgor pressure and virulence. The Mpll mutant of M. anisopliae had thinner hyphae, fewer lipid droplets (particularly in the appressoria), and a decrease in total lipids [21]. This was the first report to suggest that perilipin is a virulence determinant in insect biocontrol agents. However, little is known about the function of perilipin in mycoparasitic fungi.

C. rosea f. catenulata strain HL-1-1 was originally obtained via sclerotia baiting, and showed great potency to manage a range of fungal plant pathogens [22]. To identify mycoparasitism-related genes, a suppression subtractive hybridization ( $\mathrm{SSH}$ ) library of HL-1-1 colonizing the sclerotia of S. sclerotiorum was constructed [23]. In this study, 502 clones from the cDNA library were sequenced and analyzed, among which a perilipin-like protein coding gene, named Per3, was detected. The expression of Per3 under the induction of sclerotia was remarkably up-regulated, and the parasitic 
ability of mutants overexpressing Per3 was enhanced significantly, suggesting that perilipin might be involved in mycoparasitism of $C$. rosea f. catenulata.

\section{Results}

\subsection{Sequence Analysis of ESTs}

502 clones from the SSH cDNA library of $C$. rosea $\mathrm{f}$. catenulata HL-1-1 were sequenced, among which 472 high quality expressed sequence tags (ESTs) were identified. These ESTs were classified into 232 unigenes, including 35 contigs and 197 singletons. Of the 232 unigenes, 136 (58.6\%) showed similarity to genes with unknown functions and 53 (22.9\%) showed no similarity to any sequences in the databases and were considered as fragments of novel genes. Forty-three unigenes (18.5\%) displayed sequence similarity ( $E$-value $<10^{-5}$ ) to entries in the GenBank non-redundant protein database, exhibiting similarity to a wide range of genes involved in metabolism (e.g., aldehyde dehydrogenase, chitin synthase and fatty acid oxygenase), energy (e.g., ubiquinone oxidoreductase and ATP synthase), protein fate (e.g., ribosomal proteins and heat shock proteins), transcription (e.g., transcription factors and endonucleases), cellular transport (e.g., sodium phosphate and major facilitator superfamily (MFS) transporter), and cell rescue and defense (cytochrome P450) (Table 1). Part of the unigenes was annotated by Blast2GO software (Supplementary Table S1). Among these functional unigenes, some were related to the biocontrol process, including cell wall degrading enzyme endoglucanase [24,25], cytochrome P450 [26,27], and ubiquitin [28]. A unigene was identified that was very similar to a perilipin-like protein, which was reported as an important virulence determinant in the insect biocontrol agent $M$. anisopliae [21]. This unigene was named Per3. We determined the expression of Per3 in different parasitic stages and cloned the full-length gene from HL-1-1.

Table 1. Functional analysis of differentially expressed genes in C. rosea $\mathrm{f}$. catenulata HL-1-1 parasitizing the sclerotia of $S$. sclerotiorum by BlastX.

\begin{tabular}{|c|c|c|c|c|}
\hline Gene & $\begin{array}{l}\text { Accession } \\
\text { Number }\end{array}$ & Organism & Blast Homology Search & $E$-Value \\
\hline Per3 & ABI18161 & Metarhizium anisopliae & Perilipin-like protein & $4 e^{-44}$ \\
\hline $1-31$ & EIW51416 & Trametes versicolor & CHK1 checkpoint-like protein & $4 e^{-16}$ \\
\hline $2-9$ & EEY19892 & Verticillium alfalfae & Endoglucanase & $4 e^{-26}$ \\
\hline $2-13$ & XP_002294430 & Thalassiosira pseudonana & $\begin{array}{l}\text { rRNA intron-encoded homing } \\
\text { endonuclease }\end{array}$ & $9 e^{-23}$ \\
\hline $2-25$ & EPE03816 & Ophiostoma piceae & Sodium phosphate & $1 \mathrm{e}^{-34}$ \\
\hline $2-26$ & XP_001891758 & Brugia malayi & Transcription factor & $2 \mathrm{e}^{-23}$ \\
\hline $2-27$ & CCF47281 & $\begin{array}{l}\text { Colletotrichum } \\
\text { higginsianum }\end{array}$ & $\begin{array}{c}\text { Shwachman-Bodian-Diamond } \\
\text { syndrome protein }\end{array}$ & $2 e^{-35}$ \\
\hline $2-29$ & NP_690845 & Saccharomyces cerevisiae & $\operatorname{Tar} 1 \mathrm{p}$ & $1 \mathrm{e}^{-23}$ \\
\hline $2-49$ & XP_751750 & Aspergillus fumigatus & Fatty acid oxygenase PpoA & $2 e^{-41}$ \\
\hline $2-84$ & XP_002567725 & Penicillium chrysogenum & Pc21g06830 & $1 \mathrm{e}^{-36}$ \\
\hline $2-90$ & ELA35160 & $\begin{array}{l}\text { Colletotrichum } \\
\text { gloeosporioides }\end{array}$ & Trichothecene c- 15 hydroxylase & $7 e^{-39}$ \\
\hline $3-4$ & XP_003844958 & Leptosphaeria maculans & Similar to polyketide synthase & $2 e^{-33}$ \\
\hline $4-33$ & EJP62467 & Beauveria bassiana & 4-hydroxyphenylpyruvate dioxygenase & $5 e^{-56}$ \\
\hline
\end{tabular}


Table 1. Cont.

\begin{tabular}{|c|c|c|c|c|}
\hline Gene & $\begin{array}{l}\text { Accession } \\
\text { Number }\end{array}$ & Organism & Blast Homology Search & $E$-Value \\
\hline $4-37$ & $1101405 \mathrm{~A}$ & Saccharomyces cerevisiae & Ubiquitin precursor & $5 e^{-86}$ \\
\hline $4-47$ & EFY90398 & Metarhizium acridum & ADP,ATP carrier protein & $6 e^{-23}$ \\
\hline $4-49$ & EQK98455 & Ophiocordyceps sinensis & Glucose-repressible protein & $6 e^{-26}$ \\
\hline $5-35$ & EGC42647 & Ajellomyces capsulatus & $\begin{array}{l}\text { Transcript antisense to ribosomal } \\
\text { RNA protein }\end{array}$ & $5 \mathrm{e}^{-17}$ \\
\hline $5-84$ & EON96835 & Togninia minima & Heat shock protein 30 & $1 \mathrm{e}^{-21}$ \\
\hline $6-9$ & EJP67708 & Beauveria bassiana & $\begin{array}{c}\text { Translationally controlled tumor } \\
\text { protein-like variant I }\end{array}$ & $3 e^{-38}$ \\
\hline $6-35$ & EHK46444 & Trichoderma atroviride & Plasma membrane ATPase & $1 \mathrm{e}^{-75}$ \\
\hline $7-13$ & EFQ32165 & $\begin{array}{l}\text { Colletotrichum } \\
\text { graminicola }\end{array}$ & Cytochrome b561 & $2 \mathrm{e}^{-14}$ \\
\hline $7-32$ & EGV64838 & Candida tenuis & Ubiquitin & $2 \mathrm{e}^{-139}$ \\
\hline $7-52$ & EGS20521 & Chaetomium thermophilum & Zinc finger domain-containing protein & $2 \mathrm{e}^{-5}$ \\
\hline $7-69$ & EKG14599 & Macrophomina phaseolina & MFS transporter & $1 \mathrm{e}^{-39}$ \\
\hline $7-73$ & EQB58524 & $\begin{array}{l}\text { Colletotrichum } \\
\text { gloeosporioides }\end{array}$ & Aldehyde dehydrogenase & $2 \mathrm{e}^{-24}$ \\
\hline $7-77$ & EKD20522 & $\begin{array}{c}\text { Marssonina brunnea f. sp. } \\
\text { multigermtubi }\end{array}$ & Metallopeptidase family M24 & $5 e^{-9}$ \\
\hline $7-82$ & EFQ34155 & Glomerella graminicola & $\begin{array}{c}\text { Archaeal flagellin N-terminal-like } \\
\text { domain-containing protein }\end{array}$ & $2 \mathrm{e}^{-5}$ \\
\hline $7-85$ & ABY21303 & Mytilus trossulus & Cyp-like protein & $2 \mathrm{e}^{-13}$ \\
\hline $8-7$ & EGX92208 & Cordyceps militaris & ATP synthase subunit E & $2 e^{-15}$ \\
\hline $8-16$ & EJU02320 & Dacryopinax sp. & Plant senescence-associated protein & $2 e^{-63}$ \\
\hline $8-20$ & EGR52174 & Trichoderma reesei & Glycoside hydrolase family 16 & $2 e^{-26}$ \\
\hline $8-21$ & СCT68298 & Fusarium fujikuroi & Neutral amino acid permease & $1 \mathrm{e}^{-5}$ \\
\hline $8-22$ & EFY90747 & Metarhizium acridum & $\begin{array}{l}\text { NADH:ubiquinone oxidoreductase } \\
\qquad 18.4 \mathrm{kD} \text { subunit }\end{array}$ & $8 \mathrm{e}^{-36}$ \\
\hline $8-24$ & EGS18562 & Chaetomium thermophilum & Chitin synthase-like protein & $1 \mathrm{e}^{-8}$ \\
\hline $8-25$ & BAA10929 & Nicotiana tabacum & Cytochrome P450 like TBP & $9 \mathrm{e}^{-21}$ \\
\hline $8-48$ & EFY88095 & Metarhizium acridum & $\begin{array}{l}\text { Peptidoglycan binding domain } \\
\text { containing protein }\end{array}$ & $6 e^{-27}$ \\
\hline $8-70$ & XP_003655325 & Thielavia terrestris & Histone H4-like protein & $3 \mathrm{e}^{-54}$ \\
\hline $8-76$ & EGY21577 & Verticillium dahliae & Prohibitin-2 & $2 \mathrm{e}^{-138}$ \\
\hline $8-89$ & XP_002384050 & Aspergillus flavus & NADH-cytochrome B5 reductase & $3 e^{-60}$ \\
\hline $9-25$ & EKD19306 & $\begin{array}{c}\text { Marssonina brunnea f. sp. } \\
\text { multigermtubi }\end{array}$ & $60 \mathrm{~S}$ ribosomal protein L11 & $3 \mathrm{e}^{-9}$ \\
\hline $9-58$ & WP_005077491 & Mycobacterium abscessus & Dienelactone hydrolase & $5 e^{-39}$ \\
\hline $9-78$ & XP_002474926 & Postia placenta & Chloroperoxidase-like protein & $3 \mathrm{e}^{-5}$ \\
\hline
\end{tabular}

\subsection{Quantitative Determination of Per3 Expression}

The primer sets designed for Per3 and those for the reference gene $\beta$-tubulin successfully amplified a single product with the expected size in all experiments (Supplementary Figure S1). The identity of each 
product was confirmed by sequencing. Real-time quantitative PCR showed that the relative expression level of Per3 was down-regulated at the beginning of sclerotia induction (0-12 h). Subsequently, the expression of Per3 was up-regulated, reaching its highest level (6.6-fold over the control) at $96 \mathrm{~h}$ $(p<0.05)$ (Figure 1).

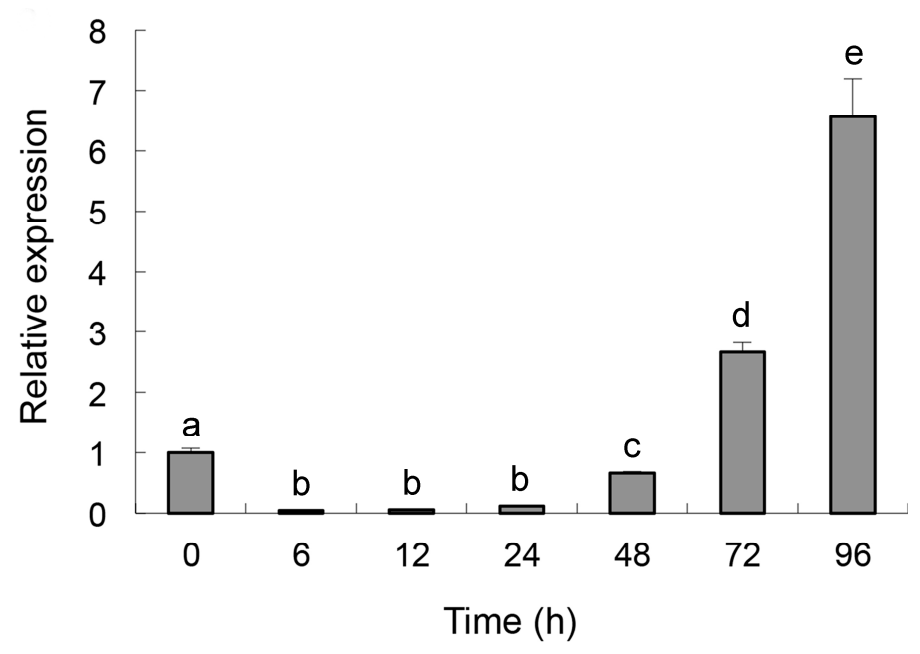

Figure 1. Expression of Per3 in C. rosea f. catenulata HL-1-1 under the induction of sclerotia of $S$. sclerotiorum, using quantitative real-time PCR. Error bars indicate the standard deviation of three replicates. Different letters represent significant differences $(p<0.05)$ according to Duncan's multiple range test.

\subsection{Cloning and Characterization of Per3}

Per3 PCR products of 500 bp and a 750 bp were obtained by 3 ' and 5' rapid amplification of cDNA ends (RACE), respectively. After gene splicing and PCR verification, a full-length cDNA of $1231 \mathrm{bp}$ was generated (Supplementary Figure S1). The complete genomic DNA sequence of Per3 was amplified using the primer pair Per3 F and Per3 R. The PCR product comprised 1284 bp with a 53 bp intron at position 377-429 (GenBank accession number KF269990).

The full-length cDNA had a 555bp open reading frame (ORF) from position 314 (ATG) to 868 (TAA), encoding a putative protein of 184 amino acids. The predicted isoelectric point (IP) of the protein was 6.08 and theoretical molecular weight was $20.2 \mathrm{kDa}$. The amino acid sequence showed high homology to perilipin-like proteins in M. anisopliae (73.3\%, ABI18161), Cordyceps militaris (62.4\%, EGX91943) and Beauveria bassiana (60.1\%, EJP62332). These comparisons indicated that Per3 contained a perilipin domain between amino acids 40 to 111 . No signal peptide, transmembrane domains or typical hydrophobic domain was detected in Per3.

Twenty amino acid sequences with high similarity to Per3 were identified using BlastP and used to construct a neighbor-joining tree to investigate the phylogeny of perilipins (Figure 2). The tree showed that Per3 from $C$. rosea f. catenulata was most closely related to that of $M$. anisopliae (73.3\%), demonstrating Per3 is a member of the perilipin family. 


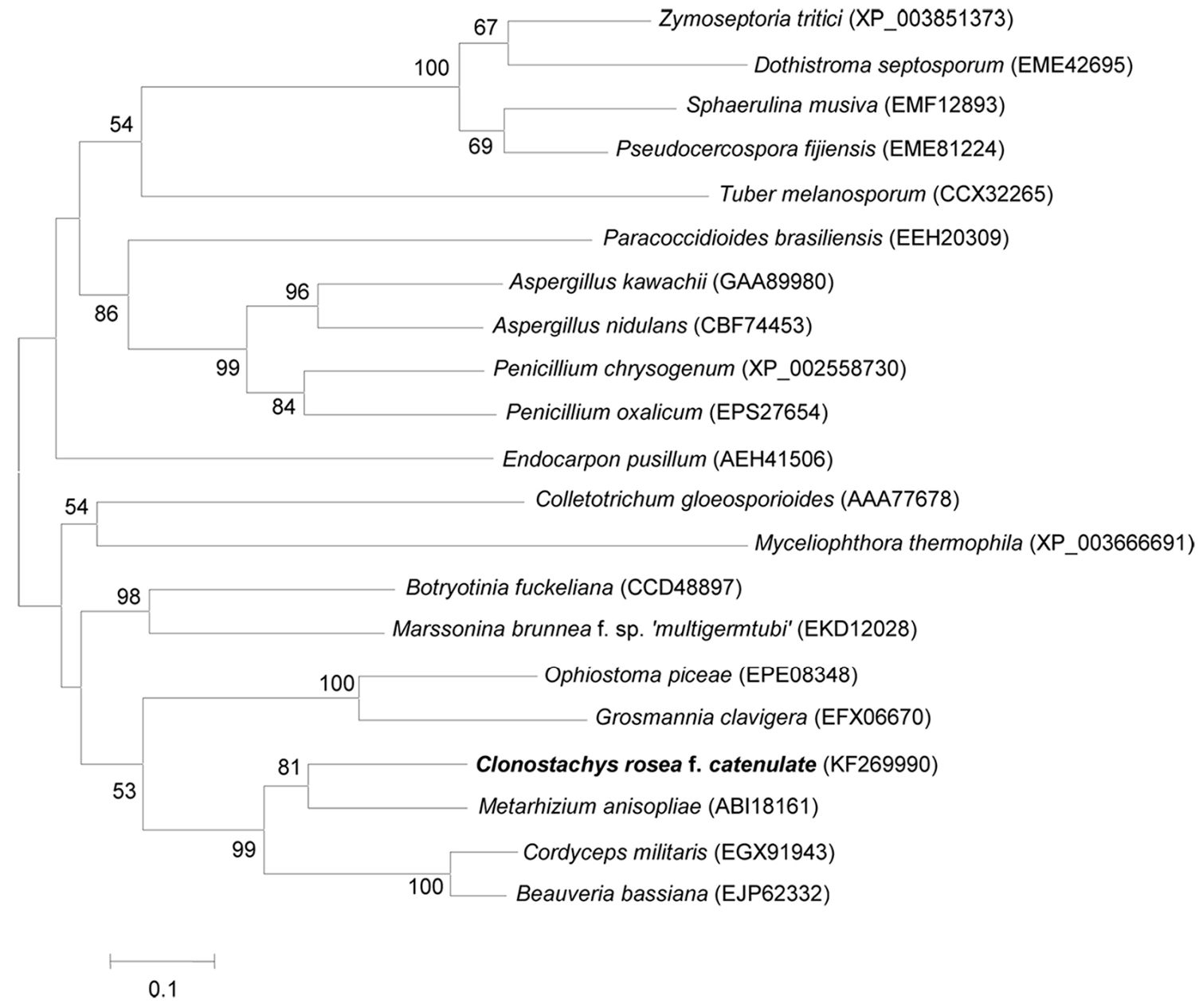

Figure 2. Neighbor-joining tree of protein Per3 from C. rosea f. catenulata HL-1-1 constructed using MEGA 5.1. Numbers in parentheses represent accession numbers in the NCBI sequence database. Numbers at the nodes indicate the bootstrap values on neighbor-joining analysis of 1000 bootstraps. Bars $(=0.1)$ represent sequence divergence.

\subsection{Overexpression of Per3 in C. rosea f. catenulate $H L-1-1$}

The Per3 gene sequence, together with $g p d A$ and $\operatorname{tr} P C$ fragments, was successfully integrated into the pAN7-1 vector, which was used to transform C. rosea f. catenulate HL-1-1. By stability verification, 320 transformants were obtained on hygromycin resistance plates. Phenotypic differences among the transformants were observed: their hyphae were either loose or dense, and the color of the colonies varied from gray to dark green. One hundred and two transformants were selected randomly and tested. There was no significant difference in the growth rate $(p>0.05)$, with colony diameters ranging from 6.02 to $7.35 \mathrm{~cm}$ in seven days. However, significant differences in sporulation were observed, with the highest level of $6.23 \times 10^{8}$ spores plate $^{-1}$ and the lowest amount of $2.35 \times 10^{7}$ spores $^{\text {plate }}{ }^{-1}(p<0.05)$.

Compared with the wild type, the mutants showed different parasitic abilities on the sclerotia of S. sclerotiorum after overexpression of $\mathrm{Per} 3$, and time after infection at which the fungal mycelia appeared on the sclerotia differed from 9 to $15 \mathrm{~h}$. Among the transformants, Pert 1-2 and Pert 2-1 showed remarkably strong parasitic abilities. Parasitism of both isolates could be observed after $9 \mathrm{~h}$ and their parasitic rates were more than $95 \%$ at $12 \mathrm{~h}$, while only $36.7 \%$ of the sclerotia were parasitized by the 
wild strain at $12 \mathrm{~h}$ (Table 2). After three days, the surfaces of the sclerotia infected by the mutants were covered with hyphae and spores of the mycoparasites, and the whole sclerotia turned to soft rot. For the wild type, the hyphae were extended and relatively loose and the sclerotia remained relatively firm, indicating that the parasitism of the Per 3 overexpressing transformants was enhanced compared with the wild type (Figure 3). Real-time PCR showed that the expression levels of Per3 in transformants Pert 1-2 and Pert 2-1 were more than twice that of the wild type (Figure 4), indicating that the increased expression level of Per3 promoted mycoparasitism of C. rosea f. catenulate HL-1-1.

Table 2. Parasitism of $C$. rosea f. catenulata HL-1-1 and Per3 gene transformants on the sclerotia of S. sclerotiorum.

\begin{tabular}{ccccc}
\hline \multirow{2}{*}{ Strain } & \multicolumn{4}{c}{ Parasitic Rate (\%) } \\
\cline { 2 - 5 } & $\mathbf{9} \mathbf{~ h}$ & $\mathbf{1 2} \mathbf{~ h}$ & $\mathbf{1 5} \mathbf{~ h}$ & $\mathbf{1 8 ~ h}$ \\
\hline HL-1-1 & $3.3 \pm 0.0^{\mathrm{a}}$ & $36.7 \pm 0.4^{\mathrm{a}}$ & $86.7 \pm 0.8^{\mathrm{a}}$ & $100.0 \pm 0.0^{\mathrm{a}}$ \\
Pert 1-2 & $30.0 \pm 0.4^{\mathrm{b}}$ & $96.7 \pm 0.7^{\mathrm{b}}$ & $100.0 \pm 0.0^{\mathrm{b}}$ & $100.0 \pm 0.0^{\mathrm{a}}$ \\
Pert 2-1 & $26.7 \pm 0.2^{\mathrm{c}}$ & $100.0 \pm 0.0^{\mathrm{c}}$ & $100.0 \pm 0.0^{\mathrm{b}}$ & $100.0 \pm 0.0^{\mathrm{a}}$ \\
\hline
\end{tabular}

Different letters in the same column represent significant differences $(p<0.05)$ according to Duncan's multiple range test.

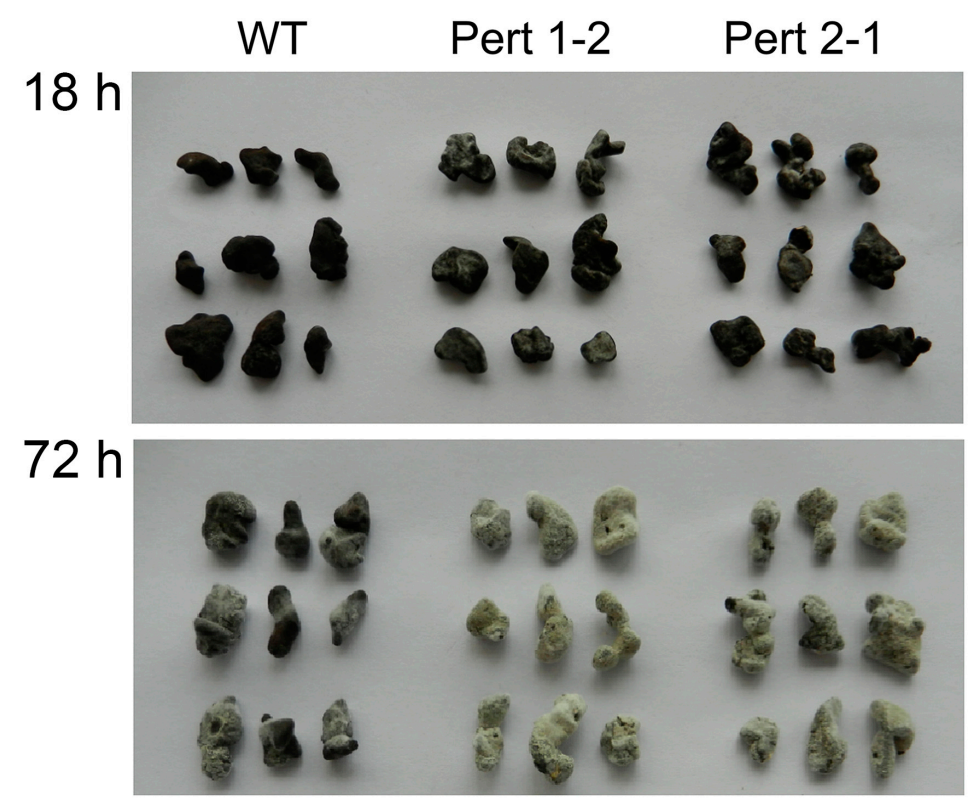

Figure 3. Parasitism of $C$. rosea f. catenulata HL-1-1 and Per3 gene transformants on sclerotia of S. sclerotiorum at different stages. Note: WT: Wild type.

\section{Discussion}

For plant disease management, it is of great value to develop biocontrol-related genes. In this study, 502 clones from the SSH cDNA library of $C$. rosea $\mathrm{f}$. catenulata HL-1-1 were sequenced, and some ESTs exhibited homology to a wide range of genes whose protein products were associated with the destruction of cell-walls and prevention of the growth of fungal pathogens, e.g., glucanase, ribosomal protein and cytochrome $\mathrm{P} 450$. These genes had been identified in mycoparasites, pathogenic fungi and plants under fungal stress [24,26,27,29]. Furthermore, a great number of ESTs with unknown 
function and potential new genes were detected in the differentially expressed cDNA library of C. rosea f. catenulata.

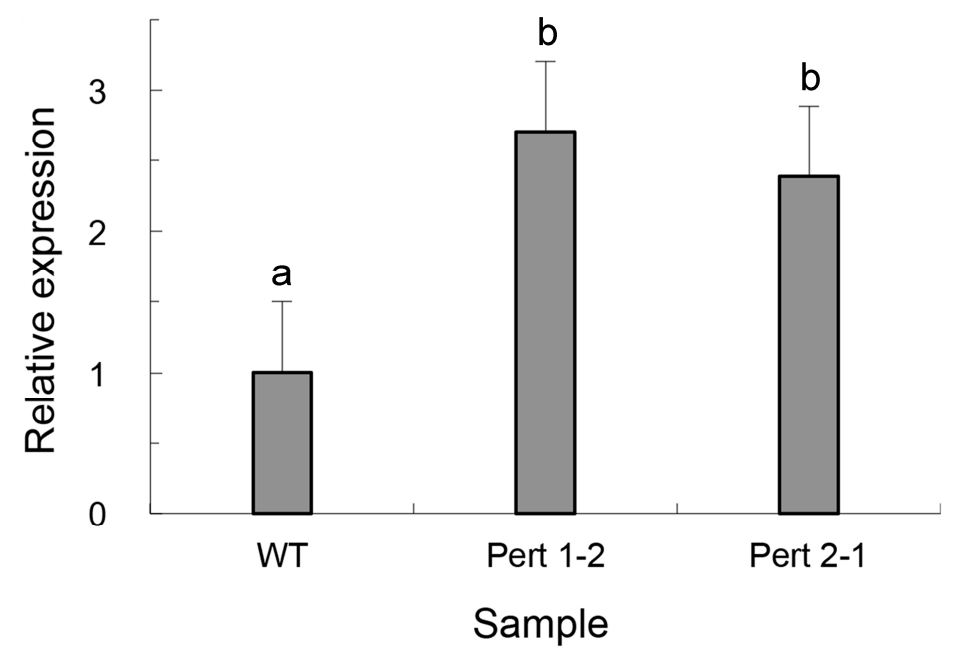

Figure 4. Expression of Per3 in HL-1-1 transformants as assessed by quantitative real-time PCR. Note: WT: Wild type. Error bars indicate the standard deviation of three replicates. Different letters represent significant differences $(p<0.05)$ according to Duncan's multiple range test.

In many cases, mycoparasites lived by saprotrophy. However, a few studies suggested that some species possess both saprotrophic and biotrophic lifestyles [30]. Mycoparasites perform their biotrophic penetration using various parasitic structures, such as appressorium. Dugan et al. found that appressoria formed in C. rosea when parasitizing on hypha of Didymella rabiei [31]. Chatterton and Punja detected an appressorium-like structure from C. rosea f. catenulate when it attached to the hyphae of $P$. aphanidermatum [4]. Trichoderma spp. could also form appressorium-like structures in the process of parasitizing the hyphae of $R$. solani [32].

A perilipin factor was reported to affect the turgor pressure of appressoria via regulating lipid droplet metabolism, and further weaken the penetration to insect cuticula [21]. Disruption of the perilipin encoding gene, $\mathrm{Mpll}$, resulted in an impaired ability to store lipid, and the appressoria of the mutant lacked lipid droplets compared with the wild type, leading to a dramatic reduction of turgor pressure and mechanical penetration to host cuticles. In our study, we selected a perilipin-like protein encoding gene, Per3, whose expression level was significantly up-regulated among these functional ESTs. Real-time quantitative PCR of Per3 showed that its expression was greatly up-regulated under induction by S. sclerotiorum, indicating that perilipin might be associated with the formation of turgor pressure in appressoria and in the process of parasitization on S. sclerotiorum. At the early stage of sclerotia induction, the expression level declined, which might reflect the lack of nutrition in the sclerotia powder medium, such that $C$. rosea f. catenulata HL-1-1 had to decompose lipid droplets through its lipid metabolic pathway to germinate and grow when it was inoculated into a nutrient-deficient broth. Accordingly, the expression level of Per3, whose protein product bound with lipid droplets, was reduced. After a period of time when HL-1-1 could obtain nutrients by decomposing the sclerotia powder, the fungus changed to storing lipid droplets instead of degrading them, and the expression level of Per3 began to increase. In the 
overexpressing transformants, higher expression of Per3 might have a greater effect on turgor pressure formation in the appressoria, which might further improve penetration of the mycoparasites.

As a member of the perilipin, adipocyte differentiation-related protein and TIP47 (PAT) family proteins, perilipin affects lipid droplet metabolism of organisms and plays a crucial role in lipid droplet motion, which is conducive to lipid homeostasis [17]. Previous studies indicated that various factors could affect the expression of perilipin genes [33-35]. In our study, when Clonostachys rosea $\mathrm{f}$. catenulata HL-1-1 was induced by sclerotia powder, the expression of perilipin changed remarkably. The selective expression of Per3 suggested that variation of the expression of perilipin protein could modulate the hydrolysis of adipocytes, and transform the states of lipid droplets between dispersion and cluster in the fungal cytoplasm, which is consistent with reports in mouse fibroblasts and Drosophila embryos [18,36].

The functional verification of Per3 by overexpressing the gene in C. rosea f. catenulata HL-1-1 during its interaction with $S$. sclerotiorum indicated that Per3 was involved in mycoparasitism. To the best of our knowledge, this is the first report of the involvement of a perilipin-like gene in mycoparasitism of $C$. rosea f. catenulata. Further study of perilipin in Clonostachys rosea f. catenulata might lead to novel methods to combat fungal plant pathogens.

\section{Experimental Section}

\subsection{Strains}

C. rosea f. catenulata HL-1-1 was isolated from a vegetable plantation in Hunan Province, and S. sclerotiorum Ss-H was separated from soybean Sclerotinia stems in field in Heilongjiang Province. Both strains are maintained in the Biocontrol of Soilborne Diseases Lab of the Institute of Plant Protection, Chinese Academy of Agricultural Sciences (CAAS).

\subsection{Preparation of Sclerotia Powder Medium}

A slope culture of S. sclerotiorum Ss-H was inoculated onto potato dextrose agar (PDA) plate andincubated at $26{ }^{\circ} \mathrm{C}$ for 7 days. The agar was cut into approximately $10 \mathrm{~mm}$ disks using a sterile puncher and inoculated into carrot medium [37] at 10-15 blocks per flask. After incubation at $26{ }^{\circ} \mathrm{C}$ for 15-20 days, sclerotia were formed in the carrot media. The remnants of the carrot media were discarded by rinsing with tap water several times, and the sclerotia were harvested. The sclerotia were then ground into 1-2 mm granules using a high-speed grinder (Hongguang Industry and Trade, Jiangsu, China). Liquid water containing $2 \%$ sclerotia powder was used as sclerotia powder broth to induce gene expression in HL-1-1.

\subsection{DNA Sequencing and Analyzing}

A total of 502 clones from the cDNA library constructed previously were selected for sequencing using the universal primer M13 on an ABI 3730XL DNA sequencer (Applied Biosystems, Foster City, CA, USA). The ESTs obtained were analyzed using Phred software (University of Washington, Seattle, WA, USA) [38]. ESTs less than $100 \mathrm{bp}$ were discarded. Clustering of ESTs into unigenes was performed using the SeqMan program (DNAStar Inc., Madison, WI, USA). 
Unigenes were compared with entries in the non-redundant (nr) and EST databases in GenBank using BlastX and BlastN (http://www.ncbi.nlm.nih.gov). Matches with an E-value below $10^{-5}$ were considered to provide biologically meaningful information. The MIPS database (http://mips.helmholtzmuenchen.de/proj/fun catDB) was used to identify the functional categories of the ESTs, and Blast2GO software (BioBam Bioinformatics S.L., Valencia, Spain) was used to obtain the GO annotations regarding biological process, molecular function and cellular components associated with the ESTs.

\subsection{RNA Extraction and cDNA Synthesis}

HL-1-1 was cultured in PD broth on a shaking table at $180 \mathrm{r} \cdot \mathrm{min}^{-1}$. After growing for 3 days at $28{ }^{\circ} \mathrm{C}$, the fermentation broth was filtered through a $25-\mu \mathrm{m}$ pore size sieve and washed five times with sterile distilled water to collect mycelia. One milliliter of mycelia suspension was inoculated into $100 \mathrm{~mL}$ sclerotia powder broth in a $500 \mathrm{~mL}$ flask, and cultured at $28^{\circ} \mathrm{C}$ on a shaking table at $180 \mathrm{r} \cdot \mathrm{min}^{-1}$. The mycelia of HL-1-1 were collected at $0,6,12,24,48,72$, and $96 \mathrm{~h}$, frozen immediately in liquid nitrogen and homogenized with sterile mortars and pestles. Total RNA was extracted using Trizol reagent (Invitrogen, Carlsbad, CA, USA) according to the manufacturer's protocol, and DNase I (Invitrogen, Carlsbad, CA, USA) was used to remove DNA contamination. First strand cDNA was synthesized using a cDNA Synthesis Kit (TaKaRa, Dalian, China) and kept at $-80^{\circ} \mathrm{C}$.

\subsection{Real-Time PCR}

Expression of perilipin-related gene Per3 was quantified by real-time PCR, in which $\beta$-tubulin was used as an internal reference gene [39]. Primer pairs for both genes were designed using the software Primer Premier 5.0 (Permier Biosoft, Palo Alto, CA, USA) (Table 3). The specificity of the primers was certified by conventional PCR with the following program: $94{ }^{\circ} \mathrm{C}$ for $3 \mathrm{~min} ; 30$ cycles of $94{ }^{\circ} \mathrm{C}$ for $1 \mathrm{~min}, 55^{\circ} \mathrm{C}$ for $30 \mathrm{~s}$ and $72{ }^{\circ} \mathrm{C}$ for $30 \mathrm{~s}$; followed by $72{ }^{\circ} \mathrm{C}$ for $10 \mathrm{~min}$.

Table 3. Primers used in the assay.

\begin{tabular}{ccc}
\hline Primers & Sequence (5'-3') & Purpose \\
\hline SPF & CGTTGTCAAGAAGCCTACCG & Real-time PCR \\
SPR & GAGGCCCTTCTGCTCAATCT & Real-time PCR \\
\hline$\beta$-tubulin $\mathrm{F}$ & CATCTTCAGACCGGTCAGTG & \multirow{2}{*}{ 3'RACE } \\
$\beta$-tubulin $\mathrm{R}$ & AAGTAGACGTTCATGCGCTC & \multirow{2}{*}{ 5'RACE } \\
\hline 3'OPF & AGATTGAGCAGAAGGGCCTC & \\
3'OPR & TCAACCAGTAAGGCGAGAAT & \multirow{2}{*}{ qdz amplification } \\
\hline 5'OPF & AGTGAGGAAGCTGCTAATCC & \multirow{2}{*}{$z z z$ amplification } \\
5'OPR & ATCTTCTTGATCTCGCTCGA & Amplification of complete DNA and full-length cDNA \\
\hline$P e r 3 \mathrm{~F}$ & GAAACTTCTCTTTCGTCTCTATCGA & \\
Per3 R & CTTGCAAGCACAGAAAGAAAATCAA & \\
\hline$q d z \mathrm{~F}$ & GAATTCCCTTGTATCTCTA & \\
$q d z \mathrm{R}$ & AAGAGAAAAGAAAAGAGCA & \\
\hline$z z z \mathrm{~F}$ & CCGACCGGGGATCCACTTA & \\
$z z z \mathrm{R}$ & GGAGTGGGCGCTTACACAG &
\end{tabular}


The samples were diluted 10-fold, and the expression level of Per3 was determined using a SYBR Premix Ex Taq (TaKaRa, Dalian, China) on an IQ $5^{\mathrm{TM}}$ multicolor real-time PCR detection system (Bio-Rad, Hercules, CA, USA). The $25 \mu \mathrm{L}$ reaction system contained $12.5 \mu \mathrm{L}$ of SYBR Premix, $2 \mu \mathrm{L}$ of diluted cDNA, $1 \mu \mathrm{L}$ of each primer, and $8.5 \mu \mathrm{L}$ of RNase-free water. Real-time PCR was performed in a 96-well plate with the following program: $95{ }^{\circ} \mathrm{C}$ for $2 \mathrm{~min}$; followed by 40 cycles of $95{ }^{\circ} \mathrm{C} 10 \mathrm{~s}, 55^{\circ} \mathrm{C} 20 \mathrm{~s}$ and $72{ }^{\circ} \mathrm{C} 30 \mathrm{~s}$. After the reaction, fluorescence values were collected every $0.5{ }^{\circ} \mathrm{C}$ from 55 to $85^{\circ} \mathrm{C}$ for 81 cycles to check for non-specific amplification. The relative expression level of Per 3 was calculated using $2^{-\Delta \Delta C t}$ method [40]. Three replicates were performed for each template at each time point.

\subsection{Cloning of Full-Length cDNA of the Per3 Gene}

The full-length cDNA of Per3 was acquired using the 5'-Full RACE Kit and 3'-Full RACE Core Set Ver. 2.0 (TaKaRa, Dalian, China), following the manufacturer's instructions. Nested PCR was carried out using LA-Taq (TaKaRa, Dalian, China) as follows: $94{ }^{\circ} \mathrm{C}$ for $3 \mathrm{~min} ; 30$ cycles of $94{ }^{\circ} \mathrm{C}$ for $1 \mathrm{~min}$, $55{ }^{\circ} \mathrm{C}$ for $30 \mathrm{~s}$ and $72{ }^{\circ} \mathrm{C}$ for $1 \mathrm{~min}$; followed by $72{ }^{\circ} \mathrm{C}$ for $10 \mathrm{~min}$. The amplified products were recovered from agarose gel using Agarose Gel DNA Fragment Recovery Kit Ver. 2.0 (TaKaRa, Dalian, China) and cloned into vector pMD19-T (TaKaRa, Dalian, China) for sequencing. By assembling products of 3 ' and 5'RACE, the full-length cDNA sequence of gene Per3 was acquired, and its validity was verified by PCR using primers $3^{\prime} \mathrm{OPF}, 3^{\prime} \mathrm{OPR}, 5^{\prime} \mathrm{OPF}$ and $5^{\prime} \mathrm{OPR}$ (Table 3), and the following program: $94{ }^{\circ} \mathrm{C}$ for $4 \mathrm{~min} ; 30$ cycles of $94{ }^{\circ} \mathrm{C}$ for $30 \mathrm{~s}, 55^{\circ} \mathrm{C}$ for $1 \mathrm{~min}$, and $72{ }^{\circ} \mathrm{C}$ for $1.5 \mathrm{~min}$; and $72{ }^{\circ} \mathrm{C}$ for $10 \mathrm{~min}$ as the final extension. The genomic DNA was extracted using a Fungal DNA Mini Kit (OmegaBio-tek, Doraville, GA, USA), and the complete DNA sequence of Per3 was amplified with the same primers and conditions as above.

\subsection{Bioinformatic Analysis of the Full-Length cDNA of Per3}

The full-length cDNA of Per3 was analyzed and compared using Blast (http://www.ncbi.nlm.nih.gov/blast/), and the ORF was predicted at ORF Finder (http://www.ncbi.nlm.nih.gov/gorf/gorf.html). The molecular weight and isoelectric point of the predicted protein were calculated by Compute pI program [41], its hydrophobicity profile was investigated by ProtScale program [42], and signal peptide prediction was conducted by Signal 4.1 program [43]. Transmembrane regions of Per3 were predicted using TMPRED software (Memorec Stoffel, Koeln, Germany) [44], and functional domains were analyzed using the Conserved Domain Database V3.10 (hppt://www.ncbi.nlm.nih.gov/Structure/cdd/cdd.shtml). Per3 was compared with similar sequences from other species, which were obtained from GenBank using Blast and aligned using DNAMAN 6.0 software (Lynnon Biosoft, Quebec, QC, Canada). Phylogenetic analysis was performed using MEGA version 5.1 with 1000 bootstraps [45], and evolutionary distances among the species were calculated using the neighbor joining method [46].

\subsection{Plasmid Construction and Transformation}

The plasmid pAN7-1, containing the promoter of the gpdA gene (glyceraldehydes-3-phosphate dehydrogenase), a termination region from $\operatorname{trpC}$ of Aspergillus nidulans [47], and a hygromycin B 
resistance gene $h p h$, was used to construct an expression vector for HL-1-1. Fragments of $g p d A$ and trpC were amplified by using PCR with primers of $q d z \mathrm{~F}, q d z \mathrm{R}$ and $z z z \mathrm{~F}, z z z \mathrm{R}$, respectively (Table 3). Plasmid pAN7-1 was digested with HindIII (TAKARA, Dalian, China) and ligated to insert the DNA of Per3 together with $g p d A$ and $\operatorname{trpC}$. Plasmid pAN7-1-Per3 was then transformed into isolate HL-1-1 by the protoplast transformation method [48]. The transformants were transferred on PDA for three generations and selected by hygromycin resistance, as described previously [48].

\subsection{Growth and Sporulation of the Transformants}

One hundred and two genetically stable transformants were selected randomly to determine their growth and sporulation in a Petri dish $(9 \mathrm{~cm})$. After growing on PDA at $26^{\circ} \mathrm{C}$ for 1 week, the colony diameters were measured and the numbers of spores were counted by eluting spores from the hyphae with $10 \mathrm{~mL}$ sterile distilled water and a glass spatula. Three replicates were conducted for each transformant.

\subsection{Mycoparasitism of the Transformants on Sclerotia of S. sclerotiorum}

S. sclerotiorum Ss-H was cultured in carrot medium at $26{ }^{\circ} \mathrm{C}$ for 10 days. The sclerotia were harvested and the medium and hyphae of Ss-H were removed by washing with sterile distilled water. A sufficient quantity of sclerotia was surface-sterilized in $75 \%$ ethanol for $45 \mathrm{~s}, 2.5 \%$ sodium hypochlorite solution for $3 \mathrm{~min}$, and $75 \%$ ethanol for $45 \mathrm{~s}$, followed by rinsing with sterile distilled water five times. The sclerotia were immersed in spore suspensions of all transformants at a concentration of $1 \times 10^{7}$ spores $\cdot \mathrm{mL}^{-1}$ for $10 \mathrm{~min}$ and then the excess water was sucked out. Twenty uniform sclerotia were placed on a wet sterile filter paper and incubated at $26^{\circ} \mathrm{C}$. The number of sclerotia parasitized by the fungal isolates was counted under an inverted microscope (BX41, Olympus, Tokyo, Japan) and a stereo-microscope (SMZ-10, Nikon, Tokyo, Japan) at 9, 12, 15, and $18 \mathrm{~h}$. Mycelia of the transformants extending on the surface of sclerotia were regarded as parasitic, and the wild type HL-1-1 was treated as the control. Three replicates were used for each transformant.

\subsection{Transcription Level of Per3 in the Transformants}

Total RNA and cDNA of the transformants with high parasitic ability on sclerotia were extracted and synthetized by using Trizol reagent (Invitrogen, Carlsbad, CA, USA) and a cDNA Synthesis Kit (TaKaRa, Dalian, China), respectively. Expression levels of Per3 in the transformants were quantified by real-time PCR using the primers of SPF and SPR (Table 3), using the same procedure described above. Three replicates were performed.

\subsection{Statistical Analysis}

The statistical software SAS 9.1.3 (SAS Institute Inc., Cary, NC, USA) was used for analysis of variance (ANOVA). Duncan's multiple range test was used to compare the means from each treatment. $p$-values $<0.05$ were considered significant. 


\section{Conclusions}

Our study identified a perilipin protein encoding gene Per3, which was obtained from a SSH cDNA library of C. rosea f. catenulata HL-1-1 parasitizing sclerotia of S. sclerotiorum. Per3 was up-regulated under the induction of sclerotia, and overexpression of Per3 significantly enhanced parasitic ability on sclerotia compared with the wild type. This study indicated that Per3 might be involved in the mycoparasitic process of $C$. rosea $\mathrm{f}$. catenulata HL-1-1.

\section{Supplementary Materials}

Supplementary materials can be found at http://www.mdpi.com/1422-0067/16/03/5347/s1.

\section{Acknowledgments}

This work was supported by the National High Technology Research and Development Program ("863" Program) of China (2011AA10A205), and the National Key Technology R\&D Program of China (2012BAD19B01). We thank Xingzhong Liu of Institute of Microbiology, Chinese Academy of Sciences for kindly providing plasmid pAN7-1. We also thank Hailei Wei of Cornell University for kindly revising this paper.

\section{Author Contributions}

Zhan-Bin Sun and Zeng-Ming Zhong performed the experiments and wrote the manuscript. Shi-Dong Li and Man-Hong Sun designed the research, analyzed the experiment data and wrote the manuscript.

\section{Conflicts of Interest}

The authors declare no conflict of interest.

\section{References}

1. McQuilken, M.P.; Gemmell, J.; Lahdenpera, M.L. Gliocladium catenulatum as a potential biological control agent of damping-off in bedding plants. J. Phytopathol. 2001, 149, 171-178.

2. Huang, H.C. Gliocladium catenulatum-hyper-parasite of Sclerotinia sclerotiorum and Fusarium species. Can. J. Bot. 1978, 56, 2243-2246.

3. Ma, G.Z.; Wu, X.R.; Yang, W.L.; Lu, G.Z. Inhibition of zymotic liquid from different isolates of Gliocladium spp. to three pathogenic fungi. J. Huazhong Agric. Univ. 2004, 23, 96-99.

4. Chatterton, S.; Punja, Z.K. Chitinase and $\beta$-1,3-glucanase enzyme production by the mycoparasite Clonostachys rosea f. catenulata against fungal plant pathogens. Can. J. Microbiol. 2009, 55, 356-367.

5. Chatterton, S.; Jayaraman, J.; Punja, Z.K. Colonization of cucumber plants by the biocontrol fungus Clonostachys rosea f. catenulate. Biol. Control. 2008, 46, 267-278. 
6. Chatterton, S.; Punja, Z.K. Interactions between Clonostachys rosea f. catenulate, Fusarium oxysporum and cucumber roots leading to biological control of fusarium root and stem rot. Recent Dev. Manag. Plant Dis. 2009, 1, 93-106.

7. Rahman, M.; Punja, Z.K. Biological control of damping-off on American ginseing (Panax quinquefolius) by Clonostachys rosea f. catenulate (=Gliocladium catenulatum). Can. J. Plant Pathol. 2007, 29, 203-207.

8. Chatterton, S.; Punja, Z.K. Factors influencing colonization of cucumber roots by Clonostachys rosea f. catenulate, a biological disease control agent. Biocontrol. Sci. Technol. 2010, 20, 37-55.

9. Steindorff, A.S.; Ramada, M.H.; Coelho, A.S.; Miller, R.N.; Pappas, G.J., Jr.; Ulhoa, C.J.; Noronha, E.F. Identification of mycoparasitism-related genes against the phytopathogens Sclerotinia sclerotiorum through transcriptome and expression profile analysis in Trichoderma harzianum. BMC Genomics 2014, 15, 204.

10. Wang, C.S.; St Leger, R.J. A scorpion neurotoxin increases the potency of a fungal insecticide. Nat. Biotechnol. 2007, 25, 1455-1456.

11. Pava-Ripoll, M.; Posada, F.J.; Momen, B.; Wang, C.S.; St Leger, R. Increased pathogenicity against coffee berry borer, Hypothenemus hampei (Coleoptera: Curculionidae) by Metarhizium anisopliae expressing the scorpion toxin (AaIT) gene. J. Invertebr. Pathol. 2008, 99, 220-226.

12. Cardoza, R.E.; Malmierca, M.G.; Gutiérrez, S. Overexpression of ergl gene in Trichoderma harzianum CECT 2413: Effect on the induction of tomato defence-related genes. J. Appl. Microbiol. 2014, 117, 812-823.

13. Kosawang, C.; Karlsson, M.; Velez, H.; Rasmussen, P.H.; Collinge, D.B.; Jensen, B.; Jensen, D.F. Zearalenone detoxification by zearalenone hydrolase is important for the antagonistic ability of Clonostachys rosea against mycotoxigenic Fusarium graminearum. Fungal Biol. 2014, 118, 364-373.

14. Dubey, M.K.; Jensen, D.F.; Karlsson, M. An ATP-binding cassette pleiotropic drug transporter protein is required for xenobiotic tolerance and antagonism in the fungal biocontrol agent Clonostachys rosea. Mol. Plant Microbe Interact. 2014, 27, 725-732.

15. Zou, C.G.; Tu, H.H.; Liu, X.Y.; Tao, N.; Zhang, K.Q. PacC in the nematophagous fungus Clonostachys rosea controls virulence to nematodes. Environ. Microbiol. 2010, 12, 1868-1877.

16. Greenberg, A.S.; Egan, J.J.; Wek, S.A.; Garty, N.B.; Blanchette-Mackie, E.J.; Londos, C. Perilipin, a major hormonally regulated adipocyte-specific phosphoprotein associated with the periphery of lipid storage droplets. J. Biol. Chem. 1991, 266, 11341-11346.

17. Bickel, P.E.; Tansey, J.T.; Welte, M.A. PAT proteins, an ancient family of lipid droplet proteins that regulate cellular lipid stores. Biochem. Biophys. Acta 2009, 1791, 419-440.

18. Marcinkiewicz, A.; Gauthier, D.; Garcia, A.; Brasaemle, D.L. The phosphorylation of serine 492 of perilipin a directs lipid droplet fragmentation and dispersion. J. Biol. Chem. 2006, 281, 11901-11909.

19. Tansey, J.T.; Sztalryd, C.; Gruia-Gray, J.; Roush, D.L.; Zee, J.V.; Gavrilova, O.; Reitman, M.L.; Deng, C.X.; Li, C.; Kimmel, A.R.; et al. Perilipin ablation results in a lean mouse with aberrant adipocyte lipolysis, enhanced leptin production, and resistance to diet-induced obesity. Proc. Natl. Acad. Sci. USA 2001, 98, 6494-6499. 
20. Teixeira, L.; Rabouilleb, C.; Rørtha, P.; Ephrussi, A.; Vanzo, N.F. Drosophila perilipin/ADRP homologue Lsd2 regulates lipid metabolism. Mech. Dev. 2003, 120, 1071-1081.

21. Wang, C.S.; St Leger, R.J. The Metarhizium anisopliae perilipin homolog MPL1 regulates lipid metabolism, appressorial turgor pressure, and virulence. J. Biol. Chem. 2007, 282, 21110-21115.

22. Ma, G.Z.; Gao, H.L.; Zhang, Y.H.; Li, S.D.; Xie, B.Y.; Wu, S.J. Purification and characterization of chitinase from Gliocladium catenulatum strain HL-1-1. Afr. J. Microbiol. Res. 2012, 6, 4377-4383.

23. Gao, H.L.; Li, S.D.; Guo, R.J.; Zhang, Y.H. Screening and analysis of differentially expressed genes in Gliocladium catenulatum parasitizing on sclerotia of Sclerotinia sclerotiorum. Chin. J. Biol. Control. 2009, 25, 48-54.

24. Giczey, G.; Kerényi, Z.; Fülöp, L.; Hornok, L. Expression of cmgl, an exo- $\beta$-1,3-glucanase gene from Coniothyrium minitans, increases during sclerotial parasitism. Appl. Environ. Microbiol. 2001, 67, 865-871.

25. Djonovic, S.; Pozo, M.J.; Kenerley, C.M. Tvbgn3, a $\beta$-1,6-glucanase from the biocontrol fungus Trichoderma virens, is involved in mycoparasitism and control of Pythium ultimum. Appl. Environ. Microbiol. 2006, 72, 7661-7670.

26. Bernardo, A.; Bai, G.; Guo, P.; Xiao, K.; Guenzi, A.C.; Ayoubi, P. Fusarium graminearum-induced changes in gene expression between Fusarium head blight-resistant and susceptible wheat cultivars. Funct. Integr. Genomics 2007, 7, 69-77.

27. Karlsson, M.; Elfstrand, M.; Stenlid, J.; Olson, A. A fungal cytochrome P450 is expressed during the interaction between the fungal pathogen Heterobasidion annosum sensu lato and conifer trees. DNA Seq. 2008, 19, 115-120.

28. Carpenter, M.A.; Stewart, A.; Ridgway, H.J. Identification of novel Trichoderma hamatum genes expressed during mycoparasitism using subtractive hybridization. FEMS Microbiol. Lett. 2005, $251,105-112$.

29. Morissette, D.C.; Dauch, A.; Beech, R.; Masson, L.; Brousseau, R.; Jabaji-Hare, S. Isolation of mycoparasitic-related transcripts by SSH during interaction of the mycoparasite Stachybotrys elegans with its host Rhizoctonia solani. Curr. Genet. 2008, 53, 67-80.

30. Atanasova, L.; Le Crom S.; Gruber, S.; Coulpier, F.; Seidl-Seiboth, V.; Kubicek, C.P.; Druzhinina, I.S. Comparative transcriptomics reveals different strategies of Trichoderma mycoparasitism. BMC Genomics 2013, 14, 121.

31. Dugan, F.M.; Lupien, S.L.; Hernandez-Bello, M.; Peever, T.L.; Chen, W. Fungi resident in chickpea debris and their suppression of growth and reproduction of Didymella rabiei under laboratory conditions. J. Phytopathol. 2005, 153, 431-439.

32. Harman, G.E.; Howell, C.R.; Viterbo, A.; Chet, I.; Lorito, M. Trichoderma species-opportunistic, avirulent plant symbionts. Nat. Rev. Microbiol. 2004, 2, 43-56.

33. Faber, B.C.; Cleutjens, K.B.; Niessen, R.L.; Aarts, P.L.; Boon, W.; Greenberg, A.S.; Kitslaar, P.J.; Tordoir, J.H.; Daemen, M.J. Identification of genes potentially involved in rupture of human atherosclerotic plaques. Circ. Res. 2001, 89, 547-554.

34. Arimura, N.; Horiba, T.; Imagawa, M.; Shimizu, M.; Sato, R. The peroxisome proliferator-activated receptor gamma regulates expression of the perilipin gene in adipocytes. J. Biol. Chem. 2004, 279, 10070-10076. 
35. Akter, M.H.; Yamaguchi, T.; Hirose, F.; Osumi, T. Perilipin, a critical regulator of fat storage and breakdown, is a target gene of estrogen receptor-related receptor $\alpha$. Biochem. Biophys. Res. Commun. 2008, 368, 563-568.

36. Welte, M.A.; Cermelli, S.; Griner, J.; Viera, A.; Guo, Y.; Kim, D.H.; Gindhart, J.G.; Gross, S.P. Regulation of lipid-droplet transport by the perilipin homolog LSD2. Curr. Biol. 2005, $15,1266-1275$.

37. Zhang, Y.; Sun, M.H.; Li, S.D.; Luo, M. Cloning and functional analysis of endoglucanase gene from Gliocladium catenulatum HL-1-1. Chin. J. Biol. Control. 2013, 29, 74-82.

38. Ewing, B.; Green, P. Base-calling of automated sequencer traces using Phred. II. error probabilities. Genome Res. 1998, 8, 186-194.

39. Mamarabadi, M.; Jensen, B.; Jensen, D.F.; Lubeck, M. Real-time RT-PCR expression analysis of chitinase and endoglucanase genes in the three-way interaction between the biocontrol strain Clonostachys rosea IK726, Botrytis cinerea and strawberry. FEMS Microbiol. Lett. 2008, 285, 101-110.

40. Livak, K.J.; Schmittgen, T.D. Analysis of relative gene expression data using real-time quantitative PCR and the $2^{-\Delta \Delta C t}$ method. Methods 2001, 25, 402-408.

41. Bjellqvist, B.; Basse, B.; Olsen, E.; Celis, J.E. Reference points for comparisons of two-dimensional maps of proteins from different human cell types defined in a $\mathrm{pH}$ scale where isoelectric points correlate with polypeptide compositions. Electrophoresis 1994, 15, 529-539.

42. Gasteiger, E.; Hoogland, C.; Gattiker, A.; Duvaud, S.; Wilkins, M.R.; Appel, R.D.; Bairoch, A. Protein identification and analysis tools on the ExPASy Server. In The Proteomics Protocols Handbook; Walker, J.M., Ed.; Humana Press Inc.: Totowa, NJ, USA, 2005; pp. 571-607.

43. Petersen, T.N.; Brunak, S.; von Heijne, G.; Nielsen, H. SignalP 4.0: Discriminating signal peptides from transmembrane regions. Nat. Methods 2011, 8, 785-786.

44. Hofmann, K.; Stoffel, W. TMbase-A database of membrane spanning proteins segments. Biol. Chem. Hoppe Seyler 1993, 374, 166.

45. Tamura, K.; Peterson, D.; Peterson, N.; Stecher, G.; Nei, M.; Kumar, S. MEGA5: Molecular evolutionary genetics analysis using maximum likelihood, evolutionary distance, and maximum parsimony methods. Mol. Biol. Evol. 2011, 28, 2731-2739.

46. Saitou, N.; Nei, M. The neighbor-joining method: a new method for reconstructing phylogenetic trees. Mol. Biol. Evol. 1987, 4, 406-425.

47. Punt, P.J.; Oliver, R.P.; Dingemanse, M.A.; Pouwels, P.H.; van den Hondel, C.A.M.J.J. Transformation of Aspergillus based on the hygromycin B resistance marker from Escherichia coli. Gene 1987, 56, 117-124.

48. Xu, M.Q.; Jiang, J.; Sun, M.H.; Xie, X.M.; Li, S.D. Construction of Clonostachys rosea 67-1 genetic transformation system by restriction enzyme-mediated integration (REMI). Chin. J. Biol. Control. 2013, 29, 263-269.

(C) 2015 by the authors; licensee MDPI, Basel, Switzerland. This article is an open access article distributed under the terms and conditions of the Creative Commons Attribution license (http://creativecommons.org/licenses/by/4.0/). 